\title{
Representation Pangulu Keris Bugis Community: Study Cultural Semiotics
}

\author{
Yusmah, Tadjuddin Maknun, Hamzah A. Machmoed, Gusnawaty \\ Linguistic Study Program, Faculty of Humanities, Hasanuddin University, Makassar
}

\begin{abstract}
This research aims to represent the meaning of pangulu in Bugis society. This type of research is a qualitative research with a descriptive analysis method. The data of this study were sourced from pengulu in the Bugis community. Data collection used participatory observation methods with interview techniques, documentation techniques, recording techniques, and note taking techniques. The results showed that the Bugis community represented Pangulu as the head or leader. In this study, it was also found that there are four types of pagulu found in the Bugis community, namely the pangulu tau-tau, the pangulu sikori, the pangulu takala and the pangulu rekko. Pangulu tau-tau are symbolized as symbols of greatness and elevation. Pangulu sikori is symbolized as a symbol of steadfastness to the leader. Pangulu takala is symbolized as a symbol of heroism and courage. While the pangulu rekko is symbolized as a symbol of obedience and obedience.
\end{abstract}

Keywords: Pangulu Keris Bugis, cultural semiotic, representation, symbol

\section{INTRODUCTION}

$\mathrm{O}$ ne of the traditional weapons that is very famous not only in Bugis society but also outside is the keris. Keris is a form of cultural manifestation of ancestral heritage in terms of continuous communication and knowledge from generation to generation. Locally, the Bugis people refer to the keris as tappi or in lontara it is usually called gajang. For the Bugis community, besides being a weapon, keris stabbing is also a reflection of the owner's social stratum, this can be seen from the characteristics of the shape of the keris it has. Keris also believed to contain metaphysical elements as spiritual items. In a keris there are three main parts, namely pangulu, wanua, and blades. Each of these parts has its own meaning. In a keris there are signs in the form or model of pengulu, while on The blade has ureq 'pamor' and sissiq. Pangulu type, pamor and sissiq or the form of visualization of the motive and its location, making a keris have high symbolic and philosophical value for the life of the Bugis people. The keris must match the weapon's shape with the body parts of the owner or according to the character of the owner. Each keris has its own function, including the function of prosperity which is good for trading, being brave and traveling to seek sustenance; the function of protecting spirits and protecting them from harm; and a brave function that gives inner strength so that the owner does not run away in fear when there is a threat from the enemy. Selection of types of pangulu, pamor and sissiq In ancient times, a keris for the Bugis was not done carelessly. The use of pangulu, pamor and sissiq in a keris has rules depending on the social strata of the wearer, so different types of pangulu, pamor and sissiq in a keris are used by aristocrats and commoners.

\section{Problem Statement}

How do pangulu keris represent in Bugis society?

\section{Objective of the research}

The purpose of this study was to determine the representation of pangulu keris in Bugis society.

\section{Significant of the research}

The benefit of this research is that the public can find out the representation of keris usage based on social strata and as a reference in further cultural semiotics research.

\section{LITERATURE REVIEW}

Etymologically, semiotics comes from the Greek semeion which means sign (Hoed in Kladen, 2018: 447; Sobur, 2016: 16). Semiotics is a science that studies signs in human life (Hoed in Kleden, 2018: 447; Sobur, 2016: 15; Noth, 2006: 3). This means that everything present in our lives is seen as a sign, that is, something that must be given meaning (Hoed, 2011:3).

Ferdinand de Saussure saw signs as the meeting between form and meaning. Saussure uses the term signifiant 'marker' for the shape of a sign, namely the sound image in one's cognition, and the signified 'sign' for its meaning, which is the content understood by humans using the sign (Hoed, 2011: 3). Thus, what is in our lives is seen as a "form" which has a certain "meaning" but is not personal but social, which is based on social conventions or conventions (Hoed, 2011: 3).

According to Barthes (in Martinet, 2010: 3), prospectively the object of semiology is all sign systems, regardless of their substance, regardless of their limit: images. Gestures, melodic sounds, objects, and various complexes composed of substances that can be found in rites, protocols, and spectacles are at least a system of significance (signification), if not a language (language).

Semiotics or in the term Barthes Semiology, basically wants to study how humanity interprets things (things). Interpreting (to sanify) means that objects not only carry information, in this case where the objects want to communicate, but also constitute a structured system of signs (Sobur, 2016: 15).

From the de Saussure concept, it is known that the object of semiotics is only speech. whereas according to Chandler (in 
Maras, 2002: 1), "semiotics involves the study not only of what we refer to as" sign "in everyday speech, but of anything which" standard for "anything else" 'semiotics is a study that is not only refers to a sign in everyday speech, but it refers to something else '. Thus, semiotics is not only in speech or writing but all in the form of signs.

Signs are various external symptoms that can be given meaning by humans. Because it relates to humans, semiotics can be used to understand culture. Fiskes (2007: 60) states that semiotics has three main fields of study, namely:

a. The sign itself. It consists in the study of the different signs, the way the different signs convey meaning, and the way they relate to the humans who use them. Signs are human constructions and humans can only be understood in terms of the humans who use them.

b. The code or system that organizes the sign. This study covers the ways these codes have been developed to meet the needs of a society or culture or to exploit the channels of communication that are willing to transmit them.

c. The culture in which codes and signs work. This in turn depends on using those codes and signs for their own existence and form.

Culture is something complex, which includes customs, moral knowledge, arts and habits acquired by humans as members of society (Koentjaraningrat, 1996: 72; Liliweri, 2016; 8). The term culture in a broad sense is something that consists of the products of action from human interaction, including human creations in the form of material or non-material.

Hoed (in Kladen 2018: 467) states that identifying semiotics in the world of cultural sciences or humanities is not too easy. However, we can see some of the main characteristics of the discipline of semiotics, one of which is when the study of semiotics enters the realm of culture, the object of study is focused on humans who are the subject of giving meaning to signs as cultural symptoms.

Anthropologists see a connection between language and culture. According to Levi Strauss, the language used reflects the culture or human behavior. Therefore, there is a similarity in concept between human language and culture. Levi Strauss argues that language can be used to study the culture or behavior of a society. A language is essentially a symbolic system that is arranged arbitrarily.

Ahimsa-Putra (2006: 24-25) states that there are three understandings of the relationship between language and culture according to Levi Strauss, namely: The

a. The language used by a society is considered a reflection of the entire culture of the community concerned.

b. Language is part of culture, or language is one of the elements of culture. c. Language is a condition for culture in a diachronic sense, meaning that language precedes culture because through language humans know the culture of society.

Based on the second meaning, language is a condition for culture because the materials used to build language are basically the same type of material as the materials that make up the culture itself, namely logical relations, opposition and correlation (Levi Strauss in Ahimsa-Putra, 2006: 25).

\section{RESEARCH METHODS}

This research is a qualitative descriptive study, which describes the representation of the meaning of pengulu keris Bugis society. The data from this study are pangulu on traditional keris weapons in Bugis society. The data collection method used in this research is a participatory observation method. The participatory observation method is carried out by interacting or being directly involved in the lives of the people being studied. The data collection techniques used in this study were interview techniques, documentation techniques, recording techniques and note taking techniques. The data analysis technique in this study is to classify the types of pangulu contained in the keris and then analyze the meaning of the pangulu.

\section{DISCUSSION}

The connotation of a pangulu means a handle or handle. In a connotation pangulu keris is considered an important part of the philosophy of the pangulu it self which can be described as a head or leader. The philosophy of a leader who submits without even having to be subdued, in the sense of a humble attitude that humanizes humans, such as the Bugis Makassar Sipakatau sipakainge sipakalebbi proverb which means to humanize, remind and respect each other.

From the type of pangulu keris it can be seen the social strata of the keris owner. Several types of pangulu found in this study are as follows:

\section{Pangulu tau-tau}

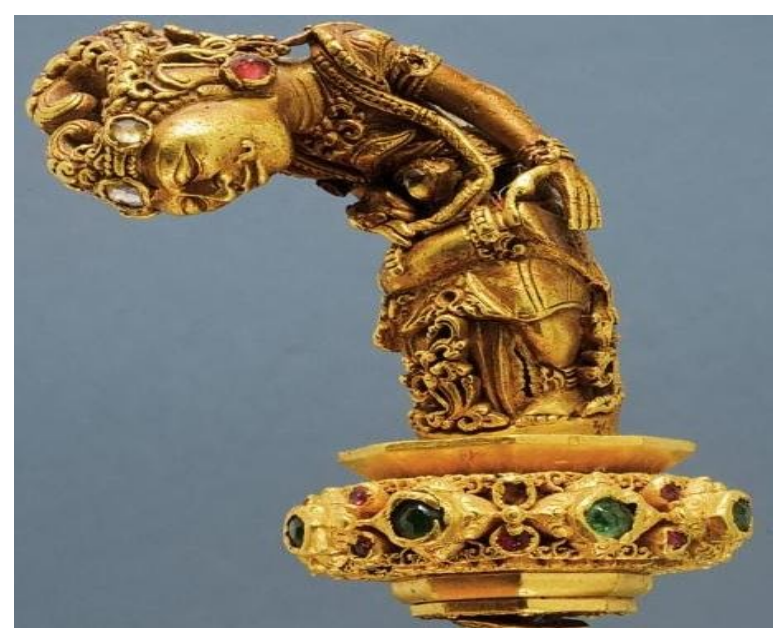

Figure 1: Pangulu tau-tau 
The type of pangulu tau-tau based on its denotation means the handle of a keris in the shape of a person. This form pangulu is in accordance with its name, namely tau-tau where the pangulu relief resembles a human body. Form pangulu In ancient times, this was only used by the highest nobility or kings. The position of the pangulu tau-tau is straight (standing upright) like a king who stands upright. Pangulu of this type is symbolized as a symbol of greatness and elevation.

\section{Pangulu Sikori}

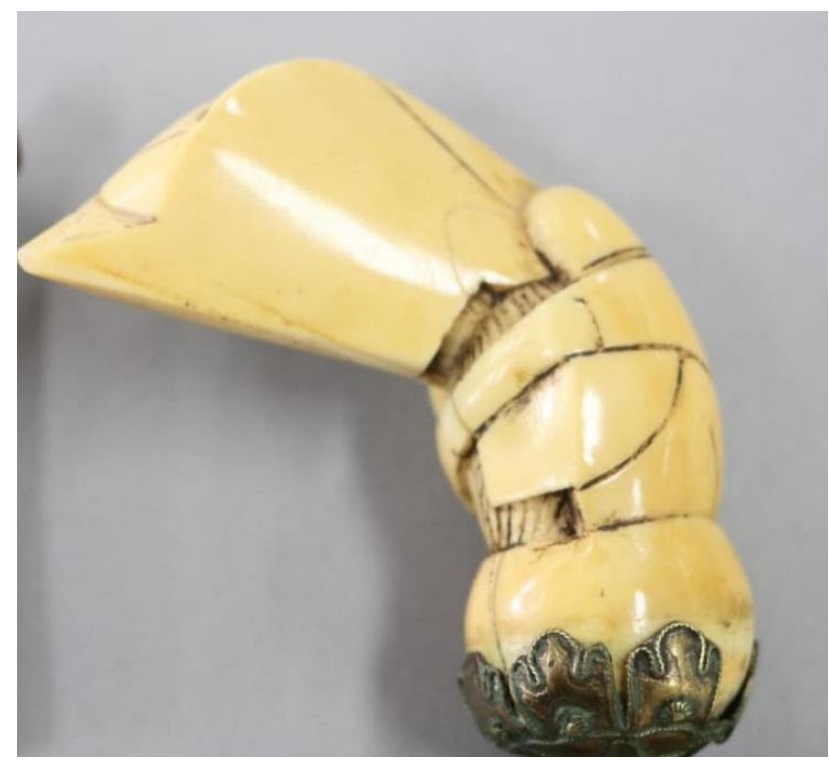

Figure 2 Pangulu Sikori

The type is pangulu not much different from the tau-tau type, but this type of pangulu looks down. In ancient times, pangulu sikori were also used by high nobility in the palace as well as warlords, the shape of a bowed head depicting a symbol of obedience and a sign of respect for the leader or king.

\section{Pangulu Takala}

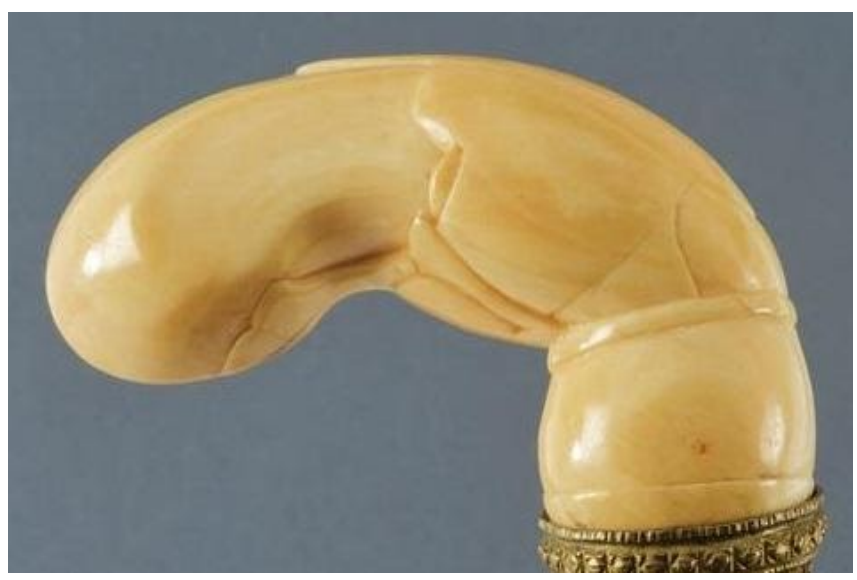

Figure 3: Pangulu Takala

The type of Pangulu takala is based on its denotation meaning alert. This Shape pangulu resembles the head of a seabird with a long neck and beak. Seabirds symbolize courage, safety and success. This type of pangulu is intended for keris used in battlefields or battles. The shape is teleng makes pangulu this keris comfortable to grip and not easily separated from the grip when used in battle. Pangulu takala is a symbol of heroism and courage.

\section{Pangulu Rekko This}

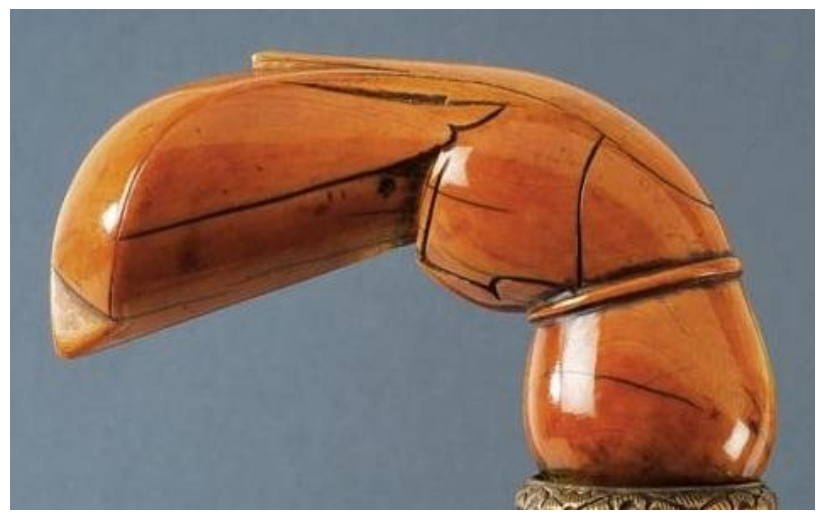

Figure 4 Pangulu Rekko This

The type of pangulu rekko which means broken denotation istype of pangulu the most widely used keris and its designation is also general. Used in various circles and for various types of functions. Pangulu rekko is a symbol of obedience and obedience. Etymologically, rekko means "to bend or bow". This is related to the belief of the Bugis people that a keris using a pangulu rekko can subdue an opponent.

\section{CONCLUSION}

Based on the above research results, the conclusion of this study is that there are four types of pangulu in the Bugis community, namely pangulu tau-tau, pangulu sikori, pangulu takala, and pangulu rekko. The four pangulu have a separate representation for the Bugis community. Pangulu tau-tau are symbols of greatness or power, pangulu sikori are symbols of obedience to the leader or king, pangulu takala are symbols of heroism and might, while pangulu rekko are symbols of obedience.

\section{REFERRENCES}

[1] Arafah, B., \& Kaharuddin, (2019). The Representation of Complaints in English and Indonesian Discourses. Opción, 35, 501-517.

[2] Arafah, Burhanuddin, Hasyim, Muhammad. (2019). Linguistic functions of emoji in social media communication. Opcion. Volume 35, No. 24, 558-574.

[3] Arafah, B., Hasyim, M. (2020). Covid-19 Mythology And Netizens Parrhesia Ideological Effects Of Coronavirus Myths On Social Media Users. Palarch's Journal of Archaeology of Egypt/Egyptology. Volume 17, Issue 4, 1398-1409

[4] Ahimsa-Putra, Heddy Shri. 2006. Strukturalisme Levi-Strauss Mitos dan Karya Sastra. Yogyakarta: Kepel Press.

[5] Berger, Arthur Asa. 2010. Pengantar Semiotika Tanda-Tanda dalam Kebudayaan Kontemporer. Yogyakarta: Tiara Wacana.

[6] Badcock, Christopher R. 2006. Levi-Strauss. Yogyakarta: Insight Reference.

[7] Barthes, Roland. 2007. Petualangan Semiologi. Yogyakarta: Pustaka Pelajar. 
[8] Barthes, Roland. 2013. Mitologi Terjemahan: Nurhadi, A. Sihabul Milah. Yogyakarta: Kreasi Wacana.

[9] Barthes, Roland. 2017. Elemen-Elemen Semiologi. Yogyakarta: Basabasi.

[10] Christomy, T dan Untung Waluyo. 2004. Semiotika Budaya. Depok: Pusat Penelitian Kemasyarakatan dan Pengabdian Masyarakat Universitas Indonesia.

[11] De Saussure, Ferdinand. 1972. Course de Linguistique Generale. Paris: Payot.

[12] Denessi, Marcel dan Paul Perron. 1999. Analizing Culture. An Introduction and Handbook. Bloomington dan Indianapolis: Indiana University Press.

[13] Hamid, Abu. 2006. Kebudayaan Bugis. Makassar: Dinas Kebudayaan dan Pariwisata Sulawesi Selatan.

[14] Hamid, Panandrang, dkk. 1990. Senjata Tradisional Daerah Sulawesi Selatan. Makassar: Departemen Pendidikan dan kebudayaan Direktorat Jendral Kebudayaan Direktorat Sejarah dan Nilai Tradisional Proyek Inventarisasi dan Pembinaan Nilai-Nilai Budaya.

[15] Hasyim, Muhammad, Nursidah, Hasjim, Munirah. (2019). Online advertising: how the consumer goods speaks to women, Opción, Volume 35, No.89, 826-845.

[16] Hasyim, Muhammad, Kuswarini, Prasuri, Masdiana. (2020) Toraja Coffee and Tourism Destination: The Sustainable Development Tourism Based on Identity of Region. Proceedings of the 5th NA International Conference on Industrial Engineering and Operations Management. IEOM Society International, 21522158.

[17] Hoed, Benny. H.2011. Semiotika dan Dinamika Sosial Budaya.Jakarta: komunitas Bambu.
[18] Kaharuddin, N. (2014). The problems of Indonesian college EFL Learners in Listening Comprehension. Jurnal ilmu budaya, 2(2).

[19] Bahar, A. K., \& Latif, I. (2019). Society-based English community (sobat): EFL learners'strategy in learning and practicing English outside the walls. Jurnal ilmu budaya, 7(2), 255-265.

[20] Kleden, Ignas dan Taufiq Abdullah. 2018. Paradigma Ilmu Pengetahuan dan Penelitian Ilmu-Ilmu Sosial dan Humaniora di Indonesia. Jakarta: Lipi Press.

[21] Koencaraningrat. 1996. Pengantar Ilmu Antropologi. Jakarta: Rineka Cipta.

[22] Kurniawan. 2011. Semiologi Roland Barthes. Magelang: Indonesiatera.

[23] Levi-Stauss, Clude. 2007. Antropologi Struktural. Yogyakarta: Kreasi Wacana.

[24] Liliweri, Alo. 2016. Konfigurasi Dasar Teori-Teori Komunikasi AntarBudaya. Bandung: Nusa Media.

[25] Maknun, Tadjuddin, Hasjim, Munira, Muslimat, Hasyim, Muhammad. 2020. The form of the traditional bamboo house in the Makassar culture: A cultural semiotic stud. Semiotica, 2020 (235), 1-12.

[26] Noth, Windfried. 1995. Handbook of Semiotics. Bloomington dan Indianapolis: Indiana University Press.

[27] Rahman, Fathu. 2017. Cyber Literature: A Reader -Writer Interactivity. International Journal of Social Sciences \& Educational Studies.), Vol.3, (4), 156-164, (Online), ISSN 24091294 (Print ISSN 2520-0968)

[28] Rusmana, Dadan M.Ag. 2014. Filsafat Semiotika. Bandung: CV. Pustaka Setia.

[29] Zoest, Aart Van. 1993. Semiotika. Diterjemahkan oleh Ani Soekawati. Jakarta: Yayasan Sumber Agung. 